\title{
REWRITING KING LEAR IN A DIASPORIC CONTEXT, REWRITING THE NATION: SECOND GENERATION AND LIFE GOES ON ${ }^{42}$
}

\author{
Rosa María García Periago, Universidad de Murcia \\ Email: rosagperiago@um.es
}

\begin{abstract}
This article explores two film adaptations of King Lear located in London in a diasporic community: Second Generation (Jon Sen 2003) and Life Goes On (Sangeeta Datta 2009). This paper examines the ways in which King Lear has to be modified to suit Non-Resident Indians. Following a diasporic framework, this article sheds light on the striking parallelisms and connections between both movies via the presence of a mother figure, two nostalgic Lears, the appearance of Muslim characters and the transformation of an extremely tragic dénouement by a happy ending. The role of the mother is especially significant since it hints at the Indian nation and the long-held association between the mother figure and India in mainstream Hindi cinema. The main hypothesis of this paper is that Second Generation and Life Goes On use Shakespeare's King Lear, which deals with the division of the kingdom, as a prism through which to approach partition. Both films relocate the action to the UK, more specifically London, since it has one of the largest Indian diasporic communities. Alluding to the colonial legacy of partition and Shakespeare and being made by diasporic filmmakers, they become postcolonial - or rather transnational works. Curiously enough, not only is King Lear rewritten and reinvented, but also Shakespeare, partition, and, ultimately, the nation, although the films offer different - and contradictory - perspectives and alternatives.
\end{abstract}

Keywords: Shakespeare, King Lear, adaptation, diaspora, partition.

42 The research of this article was done under the auspices of the research project FFI2015-68871-P "Shakespeare and the 20th century: War, Cultural Memory and New Media”. 
Resumen: Este artículo analiza dos adaptaciones cinematográficas del Rey Lear que tienen lugar en Londres en una comunidad diaspórica: Second Generation (Jon Sen 2003) y Life Goes On (Sangeeta Datta 2009). El artículo examina las diferentes formas en las que El Rey Lear se tiene que modificar para adaptarse a la diáspora india. Gracias a un marco teórico de la diáspora, el artículo se centra en los paralelismos entre las dos películas a través de la presencia de la madre, dos "reyes" caracterizados por la nostalgia, la aparición de musulmanes y la transformación de un final trágico en uno feliz. El papel de la madre es especialmente relevante, ya que hace alusión a la India y a la asociación entre la figura materna y la India en el cine de Bollywood. La hipótesis principal es que Second Generation y Life Goes On utilizan El Rey Lear, que trata sobre la división del reino, como un prisma a través del cual aproximarse a la partición en la India. Ambas localizan la acción en Reino Unido, más concretamente en Londres, ya que tiene una de las comunidades diaspóricas indias más extensas. Las películas, al aludir al legado colonial de la partición y de Shakespeare y al ser realizadas por directores diaspóricos, se convierten en trabajos postcoloniales e incluso transnacionales. Lo curioso es que no sólo se reescribe y reinventa Shakespeare a través del Rey Lear, sino también la partición en la India y, en última instancia, la nación, a pesar de que las películas ofrecen perspectivas y alternativas diferentes - e incluso contradictorias.

Palabras clave: Shakespeare, El Rey Lear, adaptación, diáspora, partición.

This paper takes as a premise the necessity to explore King Lear in a diasporic context to delve into a different understanding of Shakespeare and to reflect on Indian and diasporic social and political conditions. As necessary first steps in examining these diasporic Lears, it is worth analysing the significant role King Lear has always played on the Indian stage. Poonam Trivedi has argued that "Lear-like themes of banishment, suffering and exile" (2010: 1) have been dominant in India. In fact, Trivedi alludes to an Indian folk tale of an elderly maharajah who gets depressed when he tests his daughters' love before dividing his kingdom. When hearing that his youngest daughter claimed that she loved him like salt - a necessity - he burst in anger and disinherited her in favour of the other two. Besides, the topics of banishment and exile are also part and parcel of the great Indian epics, Ramayana and Mahabharata. Apart from these allusions, Alessandra Marino (2013: 72) even claims that the partition in King Lear resembles the division of India and Pakistan in 1947. Consequently, Lear's story is not unknown to Indian audiences and plays a crucial role in the country.

On the Indian stage, the adaptations of King Lear range from English performances - such as some made in 1832 for the Chowringhee Theatre - to Parsi theatre (localized) productions with happy endings, namely Atipidacharita in 1880. Parsi Theatre productions evoked a clear case of cultural resistance to the oppressive, imperial system governing in India at the time. As Sisir Kumar Das notices (2005: 47), the transformations of Shakespeare's oeuvre were required to address local audiences. Songs, dances, the change of language and, above all, changes in the plot were necessary to interest locals. But King Lear was not only used in the colonial period, since there were also post-colonial versions of the 
play. For instance, St. Stephen's College Shakespeare Society performed Lear in English in 1962, with a young Roshan Seth as Lear. Ebrahim Alkazi, produced a Raja Lear, in Urdu translation, for the National School of Drama in 1964, "a production that has become a benchmark of the universalized Shakespeare" (Trivedi 2010: 1). The play was translated and produced in several languages, including Bengali, Hindi, Malayalam or Tamil. The well-known Kathakali King Lear has been the object of in-depth research. ${ }^{43}$

Curiously enough, Shakespeare's play has not enjoyed the same trajectory on the Indian screen. There is a mismatch between the numerous stage productions and the scarce film adaptations or offshoots. Probably the serious nature of Shakespeare's play has contributed to the lack of adaptations of King Lear in Hindi mainstream cinema. If the troubles between the family in King Lear are reminiscent of the political scene in India, as Trivedi claims (2010: 1), the scarcity of visual materials in what is often called an "escapist" cinema is understandable. Only two movies - 36 Chowringhee Lane (Aparna Sen 1981) and The Last Lear (Rituparno Ghosh 2007) - belonging to Indian alternative or parallel cinema contain Lear figures and are freely based on the play. ${ }^{44}$ Given the lack of resources, it is worth mentioning the existence of two film adaptations of Shakespeare's King Lear in a diasporic context: Second Generation (2003), directed by Jon Sen and script by Neil Biswas and Life Goes On (2009), directed by Sangeeta Datta. Both are set in London and revolve around first and second generation diasporic beings.

This essay attempts to show the versatility of Shakespeare and how the rewriting of the play deepens not only our understanding of Shakespeare, but also of India and Indian-diasporic culture. The exploration of the role of women, first generation diasporic Lears, the role of Muslims in the films and, finally, the transformation of the endings gear toward not only a reinterpretation of the text, but also of the nation. In fact, in Second Generation and Life Goes On, King Lear becomes a site for the construction of a national (or transnational) identity in a diasporic context.

\section{DIASPORIC FILMMAKING}

Second Generation and Life Goes On should be labelled instances of accented cinema (Naficy 2001: 2) since they follow the modes of production, direction and distribution of other diasporic movies. Jon Sen is a British filmmaker and Neil Biswas is a British-Asian scriptwriter who benefitted from the Indian hype that invaded Britain in 2002 and 2003 with productions such as Tim Supple's Twelfth Night (2002). As a BBC producer claimed, "for some reason, the white middle classes [were] eating up Asian culture like fish and chips" (in Greenhalgh and Shaunnessy 2007: 99). Second Generation was a two-part TV version of King Lear commissioned by Channel Four. Neil Biswas was himself a diasporic individual, so he was familiar with two different cultures, the one of the homeland as well

43 Read for instance Ania Loomba, 'Local-manufacture made-in-India Othello fellows': Issues of race, hybridity and location in post-colonial Shakespeares'. In Ania Loomba and Martin Orkin (eds.) Post-colonial Shakespeares. London and New York: Routledge, 143-163.

44 See Rosa M. García-Periago, "English Shakespeares in India: 36 Chowringhee Lane and The Last Lear", Borrowers and Lenders: The Journal of Shakespeare and Appropriation 10.1 (2015) to read about the similarities between the films. 
as the one of the host country. Even the music - composed by the Asian underground composer Nitin Sawhney - was also part of the diasporic project. Life Goes On (2009) was directed by the Indian born but London based Sangeetta Datta. Her aim was to make a freewheeling adaptation of King Lear in modern times and in a British Asian context. According to Hamid Faficy, one of the main features of accented cinema is low budget production. These projects are often "non-commercial and usually artisanal and collective in their mode of production" (2001: 45). It is worth emphasizing that all these productions move away from artistic takes and tend to use conventional cinematic shots; they do not aim for aesthetic originality, but for content. While Channel Four was the main source of financing of Second Generation, Storm Glass Productions - a small company - produced Life Goes On. The latter was mainly screened in film festivals - it was in fact released in Mumbai film festival - and in cinemas mostly targeted at diasporic clienteles. As Keith Corson (2015: 135) claims, the main feature of the film circuit is the avoidance of popular products in favour of art films that would not find an audience otherwise. Thus, it is clear that Life Goes On is an art film, taking part in the film circuit.

The cast in Second Generation and Life Goes On needs to be analysed because it appears as an interesting example of the ghosting of actors. The most familiar example of "ghosting" of roles alludes to the process by which the audience expects to see the same actor/actress in the same role again and "producers expect to market the show more easily as a result" (Hatchuel 2011: 25). Extremely interesting is the case of Parminder Nagra who, before being the female protagonist in Second Generation, played the role of Jesminder (Jess) in Bend It Like Beckham (Gurinder Chadha 2002) and Viola in Twelfth Night (Tim Supple 2003), and thus revolutionized diasporic audiences. Consequently, she was the perfect actress for Second Generation, since audiences were already familiar with her in this kind of role. Another instance of ghosting is Om Puri, who, curiously enough, plays crucial roles in Second Generation and Life Goes On; he is King Lear in Second Generation and the fool in Life Goes On. Having acted in similar roles before, such as the successful diasporic movie East is East (Damien O'Donnell 1999), Om Puri becomes the suitable actor for such films. Regular cinemagoers are inevitably "haunted" by these ghosts of previous performances.

\section{NOSTALGIC LEARS}

Second Generation and Life Goes On are characterised by the presence of Lear figures who are Non-Resident Indians. Set in London in the 1990s, Second Generation deals with a first generation migrant called Mr Sharma (Lear), who abandoned Calcutta in the 1960s to settle in south-east London. The death of Mr Sharma's wife inevitably triggered his decision to abandon his homeland with his three daughters Pria, Rina and Heere - Gonerill, Reagan and Cordelia respectively. Starring Om Puri in the leading role, Sharma-ji appears as a typical diasporic individual, full of nostalgia for the mother country. According to Ato Quayson and Girish Daswani, "nostalgia is now commonly associated with rupture from, and the desire to one day return to, a place called home. It is also associated with the mourning of return, at least to a home as one remembers it" (2013: 17). Despite living in London, he feels alienated from his host country UK and constantly longs to return to his homeland India. Sharma-ji's alienation can be noticed in his endless attempts to maintain 
Indian customs, traditions and even food. Not surprisingly, the Lear figure is the owner of one of the most important curry businesses in London. Perhaps one of the distinguishing features of this diasporic rewriting of Shakespeare's King Lear is Lear's illness from the outset of the film. As Kenneth Muir observes (1966: 32), in the original source text, King Lear's madness starts once he feels rejected by his daughters and feels alone in the world and without possessions. However, Jon Sen's movie highlights the fact that the Lear figure is ill from the beginning. In fact, the opening scene depicts an ailing father suffering from a coma, already showing his malaise. The film anticipates his identity crisis, extremely connected to his traumatic experience. According to Paromita Chakravarti, "the Lear plot becomes the template of a narrative of death and lost legacies framed by nostalgia for a disappeared world" (2014: 139), and it is precisely this nostalgia what haunts Mr. Sharma. There is no difference between the Lear depicted at the beginning and the one halfway through the movie; if anything, his nostalgia increases and he feels completely disoriented. In fact, his nostalgia for a mythic origin and for a sense of rootedness is developed even more after Mr Kahn's death - the Gloucester-like figure. His imaginary national identity makes him idealise and venerate the homeland. For that reason, only when he returns to mother India are his problems solved; the passage to India becomes compulsory for the Lear figure.

Life Goes On equally locates King Lear in London. Although according to Suzuki Tadashi, "Lear's tragedy of solitude and madness must be brought forth not as specific to his kinship in distant time and space but as relevant to any old man living in any age in any country" (quoted in Carruthers 2009: 99), Life Goes On concentrates again on a first generation diasporic Lear - called Sanjay Banerjee - who works as a doctor. Like Second Generation, the film opens with the mother figure, paring down the original text significantly. Instead of focusing on Lear's story, the film rather revolves around the consequences caused by the mother's death and how the main characters were affected by such a loss - Dr. Sanjay Banerjee, the three daughters Lolita, Tuli and Dia (Gonerill, Reagan and Cordelia respectively) and their long-time friend Alok, who stands for the fool in King Lear. Dr. Sanjay Banerjee's nostalgia is evident from the outset of the movie when he is following a cricket match between India and Pakistan on the radio, while his wife and his friend Alok are watching it live. Throughout the film, this idea of a nostalgic Lear is only reinforced; the audience learns during Manju's funeral that he holds a powerful position in the Hindu community, like a king. He is a strict person who clings to Hindu values and traditions and plans to pass them on his three daughters with more or less luck. But the past constantly invades Banerjee; history and nostalgia mingle in this diasporic being through nightmares. With a sense of foreignness within the newly inhabited country, he cannot but remember his homeland. Nevertheless, he cannot feel at peace since when he is sleeping, he is constantly disturbed by awful memories associated with the partition of India. In the words of Földváry, "broken, fragmented images of a happy childhood are continued by equally fragmented images of violence and terror, with no continuity between them and the main narrative of the film to offer any explanation or consolation" (2013: 306). Thus, although the knowledge of his youngest daughter's relationship with a Muslim man (Imtiaz) entails a kind of madness in this Lear counterpart, his on-going nostalgic feelings are over present. Dr Sanjay Banerjee recalls the trauma originated by partition, talks on TV about it and needs to find a way to release his pain. What this diasporic Lear emphasizes is the 
similarity between the way he feels in a host country such as England and the homeland India, since partition made citizens lose everything they had, and were like refugees in their own land. Consequently, Banerjee's nostalgia cannot be solved by returning to the current homeland, but should be settled in the diasporic country.

Unlike Sharma-ji, the similarities between Lear and Dr Sanjay Banerjee go beyond the main themes and part of the plot. Ellen Dengel-Janic and Johanna Roering (2008: 212) have realized that Second Generation explores the dynamics of King Lear by retaining the three sisters and the confrontation between the father and the youngest daughter, but Life Goes On seems to go further. The film includes a play-within-the-film in which Dia plays the role of Cordelia. Interestingly, Dia is an onstage Cordelia and a real life one. The audience and Dr Banerjee learn through Manju that Lolita and Tuli referred to their father as Lear since his long-time favourite was clearly Dia. In fact, after spending the night alone, lost in the middle of nowhere trying to make sense of his life again, he sees Dia and quotes from King Lear: "Pray do not mock me, I am a very foolish old man" (4.7: 69-70). This quotation inevitably reminds us of another diasporic Lear, Miss Violet Stoneham, the protagonist of 36 Chowringhee Lane. Like Dr Banerjee, she equally quotes from King Lear to shed light on her solitude and nostalgia, but with a very different outcome. The presence of Shakespeare's King Lear in Life Goes On then plays a paramount importance, and is linked to the bond with the land.

Curiously enough, the most important scene in Shakespeare's King Lear - the division of the kingdom - is totally or partially eliminated in Second Generation and Life Goes On. In Second Generation, for instance, this scene is not included. Sharma-ji never gives up his power and authority; instead his daughters Pria and Rina take advantage of the situation, and simply take over when he is in hospital in the Intensive Care Unit with a coma. As Marino claims, "they secretly try to carry out their plan to sell the factory" (2013: 172). Obviously, the omission of this scene entails the victimisation of this King Lear. While Shakespeare's Lear is responsible for his fate and destiny, Mr Sharma is a mere victim of his daughters, and is betrayed by them. Life Goes On presents a parallel development of the story. The division of the kingdom does not take place at the beginning, but halfway through the movie. Interestingly, there is no division of the kingdom as such. Mr Banerjee simply informs his daughters of his estates, bank shares and divides his wife's jewellery among the three of them. This scene makes perfect sense in the movie after Manju's death, as he may feel his death is not long to come. It is no surprise that the scene does not take place entirely, but is interrupted by Dia's unwillingness to listen to all the properties.

If the division of the kingdom is so central in King Lear, its total or partial omission in Second Generation and Life Goes On is suspicious, and connected with nostalgia. The total or partial absence of the partition of the sovereignty provides a channel through which to explore the partition of India, since it is an allegory. Such was the trauma caused by Partition and the ensuing bloodshed in India that it can be too harsh and difficult to deal with it in movies, even via the allegory of the division of the kingdom in King Lear. Second Generation for instance shows a grim vision of London, but an idealized one of India in which there is no division of the kingdom and, for that reason, there is no partition either. The country is the home of Hindus and Muslims alike, even deleting all the allusions to Islam at the end of the film, as if all the inhabitants of India had to be Hindus. The partial inclusion of the division of 
the kingdom in Life Goes On equally bears a resemblance with the partition of British India. During the reading of his wife's will, Mr Sanjay Banerjee gets too irritated when his youngest daughter Dia claims she is not in the mood of doing it. This scene is constructed just after Dia's confession of her relationship with a Muslim boy - Imtiaz - to her father. Father and daughter overreact at this moment and demonstrate the ways in which the past is recovered in the present. Mr Sanjay Banerjee - via Dia's 'betrayal' with a Muslim - is reminded of the pain and trauma he felt during Partition when his best friend Imtiaz also betrayed him. The current situation in Life Goes On brings to life the suffering and pain of the historical past as well as the unsolved or even insolvable problems. Yet, this scene somewhat evokes a gloss of nostalgia over these events since they are connected with an ideal homeland. Both interestingly present complex, diasporic Lear figures yearning for an idealised mother country and looking for their identity once lost during Partition.

\section{MOTHER FIGURES AND NATION}

Much of the discussion around King Lear has centred around the absence of a mother figure - or even mother figures if the subplot with Edmund and Edgar is also taken into account. Coppélia Kahn, for instance, in her infamous essay entitled "The Absent Mother in King Lear" (1985) tried to uncover the hidden mother in Lear's inner self. She realised that unlike one of the main sources of King Lear, Shakespeare's play conspicuously omits the mother figure so that "the play articulates a patriarchal conception of the family in which children owe their existence to their fathers alone; the mother's role in procreation is eclipsed by the father's" (1985: 4). In spite of the fact that there is no literal mother in King Lear, Kahn pointed out the imprint of mothering on the main character through hysteria. Janet Adelman in one chapter within her book entitled Suffocating Mothers: Fantasies of Maternal Origin in Shakespeare's Plays, 'Hamlet' to 'The Tempest' (1992) cast light on Lear's tragedy as being caused by maternal deprivation. Her analysis equally emphasized the role of Cordelia as a nurturing mother.

Interestingly, the two films under analysis are characterized by the presence of a mother, who needs to be analyzed in depth to understand the implications. Instead of starting with the division of the kingdom, Second Generation's opening scene focuses on the Lear-figure called Sharma-ji being at hospital with a coma. From the outset, the movie centers around Lear's mind and hallucinations that revolve around his late wife Sonali, who committed suicide to escape the strict patriarchal codes of her society and community. Sonali's way of dying pursues Sharma-ji, who is constantly haunted by these hard and terrible memories highlighting a guilt complex. Thus, he cannot but feel guilty for his wife's death. Second Generation frequently incorporates shots of the deceased Sonali, always wearing the traditional Indian outfit saree. Really striking are the resemblances between the mother and the youngest daughter Heere. For Alessandra Marino, "mother and daughter become confused in the eye of patriarchy" (2013: 176). Apart from the obvious physical resemblances - emphasized through Parminder Nagra performing both roles - their personalities are very much alike since they are rebellious. While Sonali did not satisfy the conventional image of female roles in a patriarchal society by committing suicide, Heere also presents herself as an unruly woman due to her relationship with a white man called Jack. In Life Goes On, the mother figure is "an image presented with 
unquestioning nostalgia" (Földváry 2013: 309). To begin with, this nostalgia is boosted from the beginning for it only takes five minutes for Manju to die in Life Goes On. Like Sonali in Second Generation, all the images and shots showing Manju are presented as flashbacks. Paring down Shakespeare's play considerably, the movie revolves around Manju's death, funeral and the consequences it has rather than around the division of the kingdom, which does not appear as such. Hardly any negative aspect is shown for most of the film; Manju is depicted as a paragon of virtue. She was a domestic woman who regarded home as an inclusive territory, was in charge of passing on Bengali culture and values - as can be seen in her wardrobe full of sarees, when she supports the Indian National cricket team or when she sings Indian songs. She also united the family around her and, above all, stood for mother nature. Whenever the mother appears, she is always taking care of plants and flowers, highlighting her nurturing role. Like in Second Generation, it is the youngest daughter Dia who resembles her mother the most and maintains her spiritual essence, and also becomes a primordial nurturing force via the flowers and plants of the house. The mother's presence carries a considerable weight in Second Generation and Life Goes On.

The mother in these two movies clearly invokes the symbolic figure of Mother India or the nation; it could refer "to the country as a geographical and political unit" (Földváry 2013: 309). The mother - or rather, the suffering mother - already became a metonym for the nation in the $19^{\text {th }}$ century when India was struggling for political autonomy and independence. This idea was part of the anticolonial movement principle. In mainstream Hindi cinema, the mother figure stood for the nation especially after the independence of India and, above all, after the worst holocaust in India - partition. One typical portrayal of the female figure was as a "powerless" woman, "an object to be acted upon" (Virdi 2003: 67). The Hindu-Muslim strife triggered nostalgia. There was an idealized mythification of the mother as an attempt to reinvent an ideal Indian past. With the intention to resolve contradictions between different communities, the mother was idealized to provide a sense of unity to the population. As Virdi notes, the female figure "works as a symbol of unity, a Pan-Indian consciousness that Hindi cinema strives to project at a moment when political fragmentation is imminent" (2003: 72). But the mother figure equally entailed sacrifice, forbearance and resilience. The association between mother and nation in Hindi mainstream cinema has long existed. It probably started with Mehboob Khan's Mother India (1957), which revolved around a mother who sacrificed her own son in favour of the nation. The main character endured all the problems stoically, both nurturing, but at the same time punishing her children until in the last act of selflessness, shot her youngest son to death for turning bandit and doing mischievous acts. Starring Nargis in the lead role, she became the mother par excellance in Bollywood cinema, and immortalized the mother figure. What is commemorated in Mother India is precisely a past where women have timelessly and constantly served the nation. As Sinha claims, "Mehboob's Mother India went on to become a poster child for the patriotism inspired by the new Indian nation-state" (2006: 248). It managed to represent the major themes of the Nehruvian era but, above all, excelled in connecting woman, land and family well-being. In the subsequent decades, the mother figure continued being idealized. From the suffering mother in Amitabh Bachchan's movies usually portrayed by Nirupa Roy to the mother performed by Jaya Bachchan in the more recent Bollywood films - Kabhi Kushi Kabhie Gham (Karan Johar 2001) or Kal Ho Naa Ho (Nikhil Alvani 2003), the association between mother and nation is still pertinent. 
Manju in Life Goes On follows in the footsteps of these idealized mothers in Hindi mainstream cinema and seems to be an extension of the resilient mother figure, but the character gives fresher insight to the gender issue. Manju is the "figurehead of the familial and communal" (Bhattacharya 2011: 136) and not only stands for Mother India, but also for Mother Earth. On the one hand, she holds the family together. Her daughters Lolita, Tuli and Dia always tell their mother their dose of problems. Lolita is in an unhappy marriage, Tuli is in a lesbian relationship and Dia has a Muslim partner. On the other hand, Manju is a metonym for Mother Earth because when she appears, land, flowers and plants are involved. Curiously enough, the spectators discover throughout the movie that Manju had been unfaithful to the Lear figure with the long time friend Alok. Interestingly, there is no condemnation of the mother, but complete understanding on the daughters' behalf due to her constant loneliness. Never is Manju criticized in Life Goes On; in fact, the one who is blamed by the Lear figure is Alok for betraying their friendship. These nuances in the mother figure show an evolution in the treatment of gender in this hybrid cinema since it has tended to be very conservative and patriarchal. The mother's death involves a re-organization and reconstitution of the family. Life Goes On does not show the division of the kingdom as such, because Manju's death triggers a partition within the family; the family members are lost for a while, wandering around until Manju's spirit reunites them all again. Partition is over-present in Dr. Banerjee's mind. He frequently has nightmares which constantly bring to light the lost past with a Muslim friend and how partition put closure to that. There is a recreation of the trauma of Partition and its massacres via the mother figure. If Manju is a metonym of the nation that indirectly provokes a partition with her death - an allegory of King Lear's partition and India's partition into three countries (India, Pakistan and Bangladesh) - then, the solution provided in the movie is to come to terms with the mother's death - and, therefore, the nation's partition - in an example of Bhabha's infamous "third space," London.

Second Generation's jingoistic appropriation of the national space through the woman's body is clear from the outset. The film's opening scene depicts an ailing Lear figure unable to forget his past. Interestingly, the audience discovers that the main cause of his distress is his wife's traumatic passing - since she had committed suicide not to abide by patriarchal rules - and his unwillingness to comply with the long rooted Hindu tradition of throwing the ashes of the dead to the Ganges river to absorb the impurities. Immediately after the death, he and his three daughters leave the country and move to the diasporic location par excellence, London. Consequently, Mr. Sharma not only abandons his wife's body, but also 'Mother' India. The film forcefully reminds us of what is at stake here - the association between the mother and nation. During the twenty years Mr. Sharma has lived in London, he has not visited India once, which could be attributed to his inability to forgive his wife and, by extension, the nation. In spite of the fact he seeks to continue with his traditions in the West, he has not resolved his inner conflicts with his wife and nation, and his memory constantly reminds him of them; he is the victim of hallucinations and fits of anger. In the words of Marino, "he experiences a controversial relationship with the country that is at one and the same time the agent responsible for splitting his motherland and the 'stepmother' to which he turns, and faces the difficulties involved in raising his children in such a culturally different environment" (2013: 172). Mr. Sharma's problems are aggravated due 
to the similarities between his wife and youngest daughter. If Sonali had suffered from depression and had killed herself showing a rebellious personality, the diasporic version of Cordelia - Heere - equally appears as an independent spirit turning away from the imposed Hindu traditions, having a relationship with an Englishman called Jack and opting for exile from her family. "Sharma's troubled relation with Heere then emerges as a transposition of the intimate and conflicting dialogue the man has with Sonali during his illness" (Marino 2013: 276). Not until Mr. Sharma resolves the conflicts with his daughter Heere will he manage to come to terms with his wife - and the repressed past that keeps haunting the present - and 'Mother India'. Second Generation's climax with Mr. Sharma, Heere and Sam in the homeland reveals both the reconciliation with his deceased wife Sonali as well as with the Indian nation. The 'stepmother' England paves the way for the mother country and the mother figure where Mr. Sharma is at ease again without anxiety, madness and/ or depression. Curiously enough, what Second Generation seems to do is to reconcile Mr. Sharma with the mother/nation and, by extension, King Lear with the absent mother.

Second Generation toys with the idea of the nation, even through the actor who performs the role of King Lear's Fool, Roshan Seth. Apart from establishing the connection between the mother and the nation, the film points out one of the active agents of building the Indian nation - Nehru - via the actor. The choice of actor is not random, but based on a long list of performances in which Seth has played Nehru's role. In the words of Gautam Basu Thakur, Roshan Seth is “without a doubt the quintessential 'face' of Nehru on Indian celluloid" (2011: 86). Roshan Seth has starred as Prime Minister Nehru on endless occasions on the Indian screen: Gandhi (Richard Attenborough 1982), Food For Ravens (Griffiths 1997) and The Last Days of the Raj (Hindmarch 2007) are only some instances.

Gender and nationalist discourses are then entangled in these two movies. According to Sangeeta Datta, "nationalist discourse constitutes the female body as a privileged signifier and various struggles are waged over the meaning and ownership of that body" (2000: 73). The link between mother and nation acquires a new dimension in a diasporic context where the homeland tends to be venerated - at least by the first generation migrants - in what Tölöyan names "exilic nationalism" (2010: 34). Diasporic citizens consider not living in the mother country as a loss or deficiency. If the homeland entails the cultural identity of a country, the mother figure is in charge of transmitting these values in a diasporic context. Yet, as can be imagined, this bond is not exempt from problems since there is a clear patriarchal attitude linked to it. The interesting idea is that Life Goes On seems to challenge this view.

\section{MUSLIM CHARACTERS}

One of the remarkable similarities between Second Generation and Life Goes On has to do with the presence of Muslim characters. While Jon Sen's film includes King Lear's subplot with Gloucester - Mr. Khan - and his two sons Edmund (Firoz) and Edgar (Sam) in a Muslim family, Datta's movie basically turns the Prince of Burgundy into a Muslim character, but is not interested in reproducing the subplot. Curiously enough, Second Generation's Edgar (Sam) inevitably reminds the audience of Nahum Tate's version of King Lear due to his relationship with Cordelia's counterpart - Heere - and their happy resolution. 
In Second Generation, Mr. Hansaab Khan amalgamates two characters in one - Kent and Gloucester - and is given a terrible ending. If Kent is banished from the kingdom, Mr. Khan is fired from the curry company owned by Mr. Sharma. Furthermore, like Kent, he always supports Sharma-ji. But Mr. Khan is also indebted to Gloucester since he has two sons like him - Firoz and Sam - who are the doubles of Edmund and Edgar respectively. A twist in the plot occurs when Mr. Khan dies. Unlike Gloucester who fantasizes with death at Dover, Mr. Khan commits suicide since he felt professionally redundant and emotionally lonely. Gloucester's mere fantasy is transformed into a painful and real act that achieves intensity to sustain audience contemplation. The moment before committing suicide shows an emotional character after watching videos of the longed for past. Endless close-ups of the character crying after finding his son Firoz is having an affair with Reena or after learning about the relationship between Heere and Sam and, especially after feeling isolated advance and prepare the audience for the tragic ending. A moved and touched Khan phones his sons but he is so unlucky that nobody answers it. The audience cannot avoid thinking that no one can be so wretched in life since apart from losing his wife in childbirth twenty years ago, he is abandoned by his long-life friend and even by his sons. In fact, when Sam notices the phone call, it is just too late and his father has already committed suicide. The viewers discover the horror of the scene via a close-up of the white legs hanging on a chair and through the medium shot of Sam, feeling guilty about the dreadful death. By exploring his sudden and unexpected passing, we discover curious and interesting findings. It is to say the least appalling - that the only moment in which the rewriting is actually more depressing or bleaker than the original source is when the death of a Muslim character is involved. Gloucester was comforted by his son Edgar at the end of the play whereas Mr. Khan dies completely alone, abandoned by his sons and even with unresolved conflicts with them. Taking into account the fact that Second Generation ends as a 'feel-good' movie in a light-hearted tone, Mr. Khan's suicide needs to be explored; this death has not taken place at random, but for ulterior - and not naïve - motives. Second Generation obviously spotlights the religious dimension and religious difference at this point. It seems that the Muslim patriarch is marginalized and stigmatized in the movie to the extent he becomes a victim of this diasporic society, which is mainly Hindu, and kills himself. There are two people who commit suicide in Jon Sen's film, Mr. Khan - a Muslim - and Sonali - Sharma-ji's wife. In a way, the movie seems to establish a parallelism between Muslims and women, since they both suffer the 'stigma' of being outside the male Hindu norm.

Second Generation appears as a contradictory site of "Muslim diasporic invisibility and hypervisibility" (Alsultany and Shohat 2013: 9). Although it depicts the alienation and isolation of Muslim characters through Mr. Khan's suffering and subsequent dreadful death, the movie at the same time contributes to the increasing Islamophobia that started after 9/11 terrorist attacks and the unsavory polemics that ensued. Mr. Khan ends up being punished and, with his funeral, Muslims immediately disappear and die out. Even Sam Khan seems to forget his religion at the end of the film, where everybody seems to be a Hindu citizen in the homeland. Besides alluding to the growing wave of Islamophobia, the drama of partition is also inevitably evoked with the over-present religious conflict. Partition is not such a distant memory, but remains unsolved; it is still a tragedy in the backdrop. 
The Hindu-Muslim strife is equally present in the Sam-Heere relationship à la Nahum Tate's Edgar-Cordelia style. Grippingly, the film opens with scenes of Heere having a relationship with a white man called Jack, but the audience soon learns that she had previously had a love affair with Sam Khan. As Geraldine Harris notes, "these two had been lovers but in the past were pushed apart by parental disapproval arising from religious difference" (2006: 97). In spite of the long-lasting friendship between the two families, it had not been enough to hold them together, and religious difference got in the way. Sam and Heere emerge in Second Generation as hybrid beings trying to reconcile Indian culture with British culture, which is certainly a site of conflict. It is precisely this hybridity that characterizes them what allows them to be together again. Hybridity here should not be taken as the celebratory, triumphalist term Gayatri Chakravorty Spivak warns us against, but as a site of transformation and change "that entertains difference without an assumed or imposed hierarchy" (Bhabha 1993: 4). Although hybridity has become a buzzword in recent criticism, it generally entails conflict between two different cultures. Sam and Heere realize their similarities weigh more than their differences and their desire to be together pushes them to move forward. Religious conflict arises again when Mr. Khan learns about their union. Given that Heere is a Hindu whereas his son is a Muslim, he cannot but oppose to the relationship. That said, this impossibility of being together makes Sam and Heere look like Romeo and Juliet more than Edgar and Cordelia. The death of the Muslim patriarch gave Sam and Heere free rein to their love and union, Heere made amends to her father, decided to go back to India and, interestingly, all the references to Muslims disappear. Besides, even Sam Khan seems to have forgotten his religious background at the film's ending. Together with Heere and his father-in-law, Sam Khan has a happy-ever-after finale if it was not for the complete erosion of his customs, values and religion that the movie seems to promote. So tough was partition for Indian citizens that the solution Second Generation offers is to go back to the homeland, leave in peace there but erasing all the Muslim traces on the way.

Datta's film Life Goes On includes one main Muslim character, who also happens to be the boyfriend of Cordelia's counterpart Dia. If the cliché of forbidden unions was certainly explored in Second Generation, it was given a greater insight in Life Goes On. In fact, there is an emphasis on the strong Hindu feelings the patriarch Dr Sanjay Banerjee has. He belongs to the Hindu community in the diaspora and seems to have a good reputation there for he is highly respected. Dr. Sanjay Banerjee still recalls partition, which he regards as an upsetting and painful experience in his life and frequently has nightmares associated with it. Flashbacks in the narrative depict the horror and violence experienced during partition. Dr. Banerjee's attitude towards Muslims is therefore related to the trauma of partition. Aware of this, Dia/Cordelia tries to conceal from her father the fact that her boyfriend is a Muslim doctor. In a flashback, the audience discovers that, as usual, it was Manju the first to learn about Dia's union to Imtiaz, but she died too soon to know about Dia's pregnancy. It is precisely the discovery of the relationship between Dia and Imtiaz what causes his temporary madness; he is just unable to forgive the agony of partition and sees Muslims as active participants of his current distress. Yet, as will be seen, Shakespeare's King Lear allows Dr. Sanjay Banerjee to overcome his fears, accept his daughter's Muslim boyfriend and, overall, change radically his feelings towards Muslims and rediscover his identity in the host country. 


\section{ENDING, NATION AND PARTITION}

The most significant difference between Second Generation and Life Goes On and King Lear has to do with the ending. The tragic dénouement is transformed into a happy ending in which all the problems are solved. Jon Sen's film finishes with an understanding of most of the characters. The Goneril figure Pria Sharma reveals that she was the first one to see her mother's corpse, which has influenced her existence. Rina gets divorced since she cannot continue in an unhappy and meaningless marriage. But the film focuses most on Mr. Sharma, Heere and Sam. They abandon London and decide to go back to the homeland, which contributes to their acquisition of a deeper sense of belonging to a culture. Mr. Sharma's imaginary national identity finally finds its meaning in the motherland, erasing all his nostalgia and hallucinations. Throwing his wife's ashes to the Ganges River and going back to India help him to solve his drama. But the serial equally promotes a homogeneous, conservative - and even difficult - representation of migrant identities with the ending provided for Heere and Sam; their cultural hybridity intermingling Western and Eastern traits is controversially reduced at the end. Second Generation problematically favours the idea that hybridity is impossible and the only alternative Heere and Sam have is to embrace Indianness. All their identity conflicts will die out once they return to India and escape the "corruptions" of British life and diaspora. "What is striking here is a significant change in Heere's character: we are left with Heere bargaining in the local market, followed by a domestic scene in which she is serving food to her father and husband-to-be (Dengel-Janic and Eckstein 2008: 56). The twofold nature of British-Asian cultural identity no longer becomes manifest in Second Generation's ending. The feminist stance from the beginning paves the way for the typical insertion of the woman into a patriarchal culture and society. Gender and nation are linked once again but, unfortunately, there is no challenge of patriarchal values, but even reinforcement of them, causing more blatant stereotypes and clichés.

Life Goes On presents a parallel development of the ending, since the tragicomedy smooths the way for a happy resolution. Perhaps one of the main differences between the two rewritings of King Lear has to do with the inclusion of a play-within-the-film, which follows in the footsteps of other post-colonial revisions of Shakespeare's plays, namely Shakespeare Wallah (James Ivory 1965) or In Othello (Roysten Abel 2001). ${ }^{45}$ Dia actually played the role of Cordelia in a play within the film. Trained at the Royal Shakespeare Company (RSC), Dia and the rest of the actors of the production render Shakespeare with a perfect British accent. Thus, the production seems to propose an identification of Shakespeare with high-brow culture, since he is still presented as a British icon. Only two moments are shown of the production: the well-known beginning in which Cordelia utters the word "nothing" and immediately after, the performance moves towards Cordelia's forgiveness of her father and subsequent union and reconciliation. The production's accent on parent-child relationship is crucial for the development of the story, and advances the happy ending. As Paromita Chakravarti claims, "the reconciliation scene between Lear and Cordelia helps to resolve bitter conflicts between

45 See Richard Burt, "All that Remains of Shakespeare in Indian Film” in Dennis Kennedy and Yong Li Lan's Shakespeare in Asia: Contemporary Performance. Cambridge: Cambridge University Press to read about a considerable number of adaptations that include stagings of Shakespeare within the films. 
Sanjay and Diya, opening up a space for intergenerational dialogue and sharing" (2014: 140). It is precisely the emphasis on the reconciliation in the production what paves the way for an exploration of the conflict between father and daughter and the successful resolution.

Life Goes On's happy ending has a myriad of nuances and interesting interpretations when looked at it through the lens of South Asian popular culture. Manju's funeral entails not only the harmony between father and daughter but also within the whole family. The forgiveness of Alok's affair with Manju and the acceptance of Dia's Muslim boyfriend gear towards a blissful finale. But it is necessary to deepen into the complexities of this conclusion. Dr. Sanjay Banerjee, by forgiving his wife and his friend in the present and by consenting to his daughter's Muslim partner, is also reconciling himself with his traumatic past associated with partition. It is worth pointing out how the Lear figure even connected his daughter's boyfriend Imtiaz with his childhood friend also called Imtiaz, whom he had seen killing a neighbor during partition. Therefore, admitting the present implicitly means acknowledging the past; past and present are thus reconciled in Lear's world. The problems, conflicts and tensions faced by the Lear figure in his mother country during partition come to an end during Manju's funeral. If Manju stands for the homeland, her death can be interpreted as the "death" of conflicts within the diasporic individuals and even the "re-birth" of the nation, as death in Hinduism is associated with re-birth.

Sen and Datta's choice of King Lear as a vehicle through which to portray the tensions faced by diasporic beings shows that their rewritings of the tale are going to be full of nuances and implications. Rewriting Lear is tantamount to rewriting the nation. Yet, the conclusions provided by the movies differ considerably and are even contradictory. While Second Generation's ending seems to condemn hybridity, Life Goes On favours it and even promotes it. Second Generation focuses on the return to the homeland of Sharma-ji, Heere and Sam erasing their cultural differences and even encouraging cultural purity - as if that were possible. In contrast, Life Goes On ends with all the main characters together in London, the third space, which allows for reconciliation with the host country, the homeland, but, above all the self.

\section{CONCLUSION}

Traces of the underlying Indian history remained beneath the surface of Life Goes On and Second Generation. Both are based on King Lear, which becomes the perfect allegory for partition since it deals with the division of the kingdom. The hidden presence of partition in these two movies and the reasons for its non-explicitness, have to tell us as much about diasporic Indians and their traumas as about Shakespeare. If Shakespeare has been frequently associated with colonial India, partition is a product of colonial legacy. Thus, rewriting Shakespeare and making him postcolonial entails rewriting the past. The film adaptations echo Indian historical and cultural past and diasporic fears to finally rewrite and reinterpret Shakespeare, King Lear and, above all, their own nation. In Life Goes On and Second Generation, Shakespeare's King Lear is transformed into a story with a happy ending, and becomes a tool to create unions above all divisions and heals wounds created by a collective amnesia about partition. 


\section{REFERENCES}

36 CHOWRINGHEE LANE. Dir. Aparna Sen. India. 1981.

ADELMAN, J. 1992. Suffocating. Mothers: Fantasies of Maternal Origin in Shakespeare's Plays, Hamlet to The Tempest. New York: Routledge.

ALSULTANY, E. and E. SHOHAT. 2013. Between the Middle East and the Americas. The Cultural Politics of Diaspora. Michigan: University of Michigan.

BEND IT LIKE BECKHAM. Dir. Gurinder Chadha. UK. 2003.

BHABHA, H. 1993. The Location of Culture. New York: Routledge.

BHATTACHARYA, N. 2011. "Imagined Subjects: Law, Gender and Citizenship in Indian Cinema." Bollywood and Globalization: Indian Popular Cinema, Nation, and Diaspora. Ed. Rajeshwari V. Pandharipande. London, New York and Delhi: Anthem Press. 129-144.

BURT, R. 2010. “All that Remains of Shakespeare in Indian Film.” Shakespeare in Asia: Contemporary Performance. Ed. Dennis Kennedy and Yong Li Lan. Cambridge: Cambridge University Press. 73-108.

CARRUTHERS, I. 2009. "Fooling with Lear". Replaying Shakespeare in Asia. Eds. Poonam Trivedi and Minami Ryuta. New York and London: Routledge. 97-118.

CHAKRAVARTI, P. 2014. “Interrogating 'Bollywood Shakespeare': Reading Rituparno Ghosh's The Last Lear”. Bollywood Shakespeares. Eds. Craig Dionne and Parmita Kapadia. London and New York: Palgrave Macmillan. 127-145.

CORSON, K. 2015. "Little Indias: Diasporic Communities in the US and the Consumption of Bollywood." Shaping Indian Diaspora: Literary Representations and Bollywood Consumption. Eds. Cristina M. Gámez-Fernández and Deena Dwivedi. London: Lexington Books. 133-146.

DAS, S. K. 2005. “Shakespeare in Indian Languages.” India’s Shakespeare: Translation, Interpretation and Performance. Eds. Poonam Trivedi and Dennis Bartholomeusz. Newark: University of Delaware Press. 47-73.

DATTA, S. 2000. "Globalisation and Representations of Women in Indian Cinema", Social Scientist 28.3/4: 71-82.

DENGEL-JANIC, E. and L. ECKSTEIN. 2008. "Bridehood Revisited: Disarming Concepts of Gender and Culture in Recent Asian British Film". Multi-ethnic Britain 2000+ New Perspectives in Literature, Film and the Arts. Eds. Lars Eckstein, Barbara Korte, Eva Ulrike Pirker and Christoph Reinfandt. Amsterdam: Rodopi. 45-64.

DENGEL-JANIC, E. and J. ROERING. 2008. "Re-Imaging Shakespeare in Second Generation - A British-Asian Perspective on Shakespeare's King Lear." Drama and Cultural Change: Turning Around Shakespeare. Eds. Matthias Bauer and Angelika Zirker. Trier: WVT. 211-219.

EAST IS EAST. Dir. Damien O’Donnell. UK. 1999. 
FOOD FOR RAVENS. Dir. Trevor Griffiths. UK. 1997.

FÖLDVÁRY, K. 2013. "Postcolonial Hybridity: The Making of a Bollywood Lear in London," Shakespeare 9.3: 304-312.

GANDHI. Dir. Richard Attenborough. UK. 1982.

GARCÍA-PERIAGO, R.M. 2015. "English Shakespeares in India: 36 Chowringhee Lane and The Last Lear," Borrowers and Lenders: The Journal of Shakespeare and Appropriation 9.

GREENHALGH, S. and R. SHAUNNESSY. 2006. “Our Shakespeares: British Television and the Strains of Multiculturalism." Screening Shakespeare in the Twenty-First Century. Eds. Mark Thornton Burnett and Ramona Wray. Edinburgh: Edinburgh University Press. 90-112.

HARRIS, G. 2006. Beyond Representation: Television Drama and the Politics and Aesthetics of Identity. Manchester: Manchester University Press.

HATCHUEL, S. 2011. Shakespeare and the Cleopatra/Caesar Intertext: Sequel, Conflation, Remake. Lanham: Fairleigh Dickinson University Press.

IN OTHELLO. Dir. Roysten Abel. India. 2001.

KABHIE KUSHI KABHI GHAM. Dir. Karan Johar. India. 2001.

KAHN, COPPÉLIA. 1985. “The Absent Mother in King Lear.” Rewriting the Renaissance: The Discourses of Sexual Difference. Eds. Margaret Ferguson, Maureen Quilligan, and Nancy Vickers. Chicago: University of Chicago Press. 33-49.

KAL HO NAA HO. Dir. Nikhil Alvani. India. 2003.

LIFE GOES ON. Dir. Sangeeta Datta. UK. 2009.

LOOMBA, A. 1998. "Local-manufacture made-in-India Othello fellows': Issues of race, hybridity and location in post-colonial Shakespeares"'. Post-colonial Shakespeares. Eds. Ania Loomba and Martin Orkin. London and New York: Routledge. $143-163$.

MARINO, A. 2013. “Cut'n'mix King Lear: Second Generation and British-Asian Identities." Shakespeare and Conflict: A European Perspective. Eds. Carla Dente and Sara Soncini. London and New York: Palgrave Macmillan. 170-183.

MOTHER INDIA. Dir. Mehboob Khan. India. 1957.

MUIR, K. 1966. “Madness in King Lear”, Shakespeare Survey 13: 30-40.

NAFICY, H. 2001. An Accented Cinema: Exilic and Diasporic Filmmaking. Princeton: Princeton University Press.

QUAYSON, A. and G. DASWANI. 2013. A Companion to Diaspora and Transnationalism. Wiley Blackwell.

SECOND GENERATION. Dir. Jon Sen. UK. 2003. 
SHAKESPEARE, W. 1986. Complete Works. Edited by Stanley Wells et al. Oxford: Clarendon Press.

SHAKESPEARE WALLAH. Dir. James Ivory. UK. 1965.

SINHA, M. 2006. Specters of Mother India. The Global Restructuring of an Empire. Duke: Duke University Press.

SPIVAK, G. C. 2003. A Critique of Postcolonial Reason. Cambridge: Harvard University Press.

THAKUR, G. 2011. "Globalization and the Cultural Imaginary: Constructions of Subjectivity, Freedom and Enjoyment in Popular Indian Cinema." Bollywood and Globalization: Indian Popular Cinema, Nation and Diaspora. Eds. Rini Bhattacharya Mehta and Rajeshwari Pandharipande. London, New York and Delhi: Anthem Press. 75-92.

THE LAST DAYS OF THE RAJ. Dir. Carl Hindmarch. UK. 2007.

THE LAST LEAR. Dir. Rituparno Ghosh. India. 2007.

TÖLÖYAN, K. 2010. “Beyond the Homeland: From Exilic Nationalism to Diasporic Transnationalism”. The Call of the Homeland: Diaspora Nationalisms, Past and Present. Eds. Allon Gal, Athena S. Leoussi and Anthony D. Smith. Leiden and Boston: Brill. 27-46.

TRIVEDI, P. 2010. "Shakespeare in India: History of King Lear in India”. MIT Global Shakespeares. Video and Performance Archives. http://globalshakespeares.mit.edu/ blog/2010/06/22/history-of-king-lear-in-india/ Last accessed 07/08/2015.

TWELFTH NIGHT. Dir. Tim Supple. UK. 2002.

VIRDI, J. 2003. The Cinematic ImagiNation: Indian Popular Films as Social History. New Brunswick, New Jersey and London: Rutgers University Press. 